\title{
BENEISH RATIO INDEX SEBAGAI ALAT DETEKSI KECURANGAN LAPORAN KEUANGAN PADA PERUSAHAAN MANUFAKTUR
}

\author{
Zulzilawati ${ }^{1}$, Nanik Wahyuni ${ }^{2}$ \\ Universitas Islam Negeri Maulana Malik Ibrahim Malang1,2 \\ Jl. Gajayana No. 50 Malang \\ e-mail : nanik@akuntansi.uin-malang.ac.id ${ }^{1}$
}

\section{Abstract}

The purpose of this study is to determine the number and detect companies that commit fraud so that companies can be categorized as manipulators, non-manipulators and gray companies. This research uses quantitative research with descriptive approach. The object used in this study is a Manufacturing Company listed on the Indonesia Stock Exchange (IDX) in 2016-2019. The research sample was taken using purposive sampling technique. This study analyzes data using eight types of financial ratios contained in the Beneish Ratio Index method. The results showed that the manufacturing companies classified as the most manipulators in 2017. Then the manufacturing companies classified as the most non-manipulators in 2019 were 52 companies. Furthermore, the largest number of manufacturing companies classified as gray companies in 2016 and 2018 were 5 companies.

Keywords : Beneish Ratio Index, Financial report fraud detection, Manipulator, Nonmanipulator, Grey Company.

Abstrak

Tujuan dari penelitian ini adalah untuk mengetahui jumlah dan mendeteksi perusahaan yang melakukan tindak kecurangan sehingga perusahaan bisa dikategorikan sebagai manipulator, non-manipulator dan grey company terjadi,. Penelitian ini menggunakan jenis penelitian kuantitatif dengan pendekatan deskriptif. Objek yang digunakan dalam penelitian ini adalah Perusahaan Manufaktur yang terdaftar dalam Bursa Efek Indonesia (BEI) tahun 2016-2019. Sampel penelitian diambil dengan menggunakan teknik purposive sampling. Penelitian ini melakukan analisis data dengan menggunakan delapan jenis rasio keuangan yang terdapat dalam metode Beneish Ratio Index. Hasil penelitian menunjukkan bahwa perusahaan manufaktur yang tergolong manipulator terbnayak pada tahun 2017. Kemudian perusahaan manufaktur yang tergolong non-manipulator terbanyak pada tahun 2019 ada 52 perusahaan. Selanjutnya, perusahaan manufaktur yang tergolong grey company terbanyak pada tahun 2016 dan 2018 yaitu sebanyak 5 perusahaan.

Kata kunci: Beneish Ratio Index, Deteksi Kecurangan Laporan Keuangan, Manipulator, Non-manipulator, Grey Company.

\section{PENDAHULUAN}

Kecurangan merupakan salah satu tindakan ilegal yang dilakukan dengan sengaja, melanggar standar, hukum serta Struktur Pengendalian Internal (SPI) perusahaan demi mendapatkan keuntungan pribadi maupun kelompok (Dinasmara dan Adiwibowo, 2020: 3). Kecurangan dalam sisi audit merupakan tindakan salah saji dalam laporan keuangan, yang dilakukan dengan sengaja. Dalam melakukan kecurangan, biasanya pelaku melakukan tiga langkah, yaitu tindakan, penyembunyian, dan konversi. Association of Certified Fraud Examinations (ACFE, 2019: 14) menyatakan bahwa terdapat tiga bentuk kecurangan, yaitu korupsi (coruption), penyalahgunaan aset atau kekayaan negara dan 
Zulzilawati dan Nanik Wahyuni : Beneish Ratio Index Sebagai Alat Deteksi Kecurangan Laporan Keuangan Pada Perusahaan Manufaktur

perusahaan (asset misappropriation), serta kecurangan laporan keuangan (financial statement fraud). Deteksi kecurangan pada laporan keuangan dengan menggunakan Beneish Ratio Index dinilai cukup efektif. Hal ini dibuktikan oleh penelitian Omar et al. (2014), dimana hasil penelitiannya menunjukkan bahwa perusahaan bernama Megan Media Holdings Berhard (MMHB) terindikasi melakukan kecurangan laporan keuangan. Metode ini mendeteksi dengan tepat, karena diketahui MMHB telah melakukan kecurangan dengan melakukan pencatatan fiktif pada akun pendapatan senilai RM228 juta atau $75 \%$ lebih tinggi dari pendapatan sebenarnya (Mondovisione.com). Survei yang dilakukan oleh ACFE Indonesia pada tahun 2019, menunjukkan bahwa bentuk kecurangan yang paling merugikan di Indonesia adalah korupsi. Hasil survei ini berbeda dengan hasil survei ACFE secara global, dimana bentuk kecurangan yang paling merugikan adalah kecurangan laporan keuangan. Meskipun fraud dalam bentuk kecurangan laporan keuangan memiliki persentase paling rendah, namun menurut hasil survei secara global bentuk kecurangan inilah yang memberi kerugian paling besar, yaitu mencapai nilai USD700.000.

Salah satu kasus kecurangan laporan keuangan terbesar yang pernah terjadi secara global adalah Enron, yaitu perusahaan yang bergerak dalam sektor komoditas energi di Amerika Serikat. Enron melakukan modifikasi pada laporan keuangannya agar penyajianya terlihat sesuai dengan standar akuntansi yang berlaku umum. Pihak manajemen menggunakan berbagai teknik akuntansi dengan tujuan untuk menaikkan pendapatan perusahaan sebesar USD600 juta dan menyembunyikan hutang yang dimiliki sebesar USD1,2 miliar. Kasus kecurangan ini, juga melibatkan auditor eksternal yaitu KAP Arthur Andersen untuk membantu menutupi kecurangannya. Atas tindak kecurangan ini, Enron menyebabkan para pemegang saham mengalami kerugian sebesar USD70 miliar serta 20.000 karyawan kehilangan mata pencaharian karena Enron mengalami kebangkrutan (Bbc.com). Tidak hanya itu, masyarakat telah kehilangan kepercayaan pada Enron dan mempertanyakan integritas dari laporan keuangannya. Kasus kecurangan ini juga menyebabkan penutupan KAP Arthur Andersen, sehingga 85.000 karyawan kehilangan pekerjaan (Reflusmen, 2010).

Banyaknya kasus kecurangan laporan keuangan di Indonesia diperkuat oleh penelitian yang dilakukan oleh Christy dan Stephanus (2018), dimana selama tahun 2014 sampai dengan 2016, sebanyak 32 Perusahaan Perbankan terdeteksi melakukan kecurangan laporan keuangan. Kemudian, pada tahun 2016 sampai dengan 2017 terdapat 4 Perusahaan Konsumsi di Bursa Efek Indonesia terindikasi melakukan kecurangan laporan keuangan (Kurnianingsih dan Siregar, 2019). Selanjutnya, terdapat 9 perusahaan yang melakukan IPO pada tahun 2018 juga terindikasi melakukan kecurangan laporan keuangan (Latifatussolikhah dan Pertiwi, 2020).

Berdasarkan kasus-kasus kecurangan diatas, diketahui bahwa kecurangan memiliki konsekuensi berat bagi perekonomian negara, perusahaan, maupun individu (Priantara, 2013: 211). Konsekuensi yang diterima perusahaan adalah mendapat berbagai macam kerugian, baik dalam bentuk keuangan ataupun non-keuangan, seperti tercemarnya nama baik perusahaan yang mana akan berdampak pada kelangsungan usaha yang 
dijalankan. Kerugian yang terjadi, tidak hanya dialami oleh perusahaan itu sendiri namun juga pihak lain yang bersangkutan.

Objek yang digunakan dalam penelitian ini adalah perusahaan manufaktur, hal ini dikarenakan industri manufaktur memiliki unit usaha yang lebih kompleks dibandingkan dengan jenis usaha lain, sehingga peluang terjadinya kecurangan lebih besar. Selain itu menurut survei ACFE secara global, perusahaan manufaktur menempati posisi pertama sebagai jenis usaha yang melakukan tindak kecurangan. Adapun tujuan penelitian ini adalah untuk mengetahui jumlah perusahaan yang tergolong manipulator, non-manipulator, dan grey company untuk melakukan deteksi tindak kecurangan pada laporan keuangan perusahaan pada Perusahaan Manufaktur yang terdaftar dalam Bursa Efek Indonesia (BEI) tahun 2016-2019.

\section{KAJIAN PUSTAKA}

Beneish Ratio Index merupakan alat deteksi kecurangan pada laporan keuangan dengan menggunakan delapan jenis rasio, yaitu Days Sales In Receivables Index (DSRI), Gross Margin Index (GMI), Asset Quality Index (AQI), Sales Growth Index (SGI), Depreciation Index (DEPI), Sales, General, and Administrative Expense Index (SGAI), Leverage Index (LVGI) dan Total Accrual To Total Assets Index (TATA) (Beneish, 1999). Metode ini membantu penggunanya mendeteksi kecurangan dan untuk mengkategorikan perusahaan yang dianalisis menjadi tiga golongan, yaitu manipulator merupakan golongan bagi perusahaan yang terindikasi melakukan kecurangan laporan keuangan, non-manipulator ialah golongan bagi perusahaan yang terindikasi tidak melakukan kecurangan laporan keuangan, dan grey company merupakan golongan bagi perusahaan yang terindikasi melakukan kecurangan, namun nilainya tidak material (Mantone, 2013 dalam Latifatussolikhah dan Pertiwi, 2020: 164).

\section{METODE}

Penelitian ini menggunakan jenis penelitian kuantitatif, dengan pendekatan deskriptif. Penelitian ini menggunakan data sekunder, yaitu laporan keuangan tahunan. Laporan keuangan tahunan tersebut didapatkan dari situs resmi Bursa Efek Indonesia (BEI), yaitu www.idx.co.id. Populasi dalam penelitian ini adalah Perusahaan Manufaktur yang terdaftar di Bursa Efek Indonesia (BEI) pada tahun 2016 sampai dengan tahun 2019 yang berjumlah 182 perusahaan. Sedangkan sampel dalam penelitian ini merupakan Perusahaan Manufaktur yang terdaftar di Bursa Efek Indonesia pada tahun 2016-2019 yang telah memenuhi kriteria sampel pada penelitian ini. Jumlah sampel yang digunakan dalam penelitian ini, yaitu sebanyak 55 perusahaan dengan masa pengamatan selama 4 tahun, sehingga jumlah sampel yang diolah sebanyak 220 perusahaan.

Sampel yang digunakan dalam penelitian ini diambil dengan menggunakan tenik purposive sampling atau judmental sampling. 
Adapun langkah-langkah yang diambil peneliti dalam melakukan analisis data, antara lain:

1. Menghitung besarnya nilai indeks rasio yang terkandung dalam Beneish Rasio Index berdasarkan data yang tersaji dalam laporan keuangan Perusahaan Manufaktur yang menjadi sampel dalam penelitian ini. Rasio indeks yang dimaksud meliputi:

a. Days Sales In Receivables Index (DSRI), digunakan untuk mengukur ada tidaknya keseimbangan (out of balance) antara piutang dengan pendapatan selama dua tahun berturut-turut. Rasio ini dihitung menggunakan rumus:

$$
\text { DSRI }=\frac{\left(\frac{\text { Net Receivablest }_{t}}{\text { Salest }_{t}}\right)}{\left(\frac{\text { Net Recervablest }}{\text { Sales }_{t-1}}\right)}
$$

Dimana:

Sales $_{\mathrm{t}} \quad$ : Penjualan pada periode berjalan

Sales $\mathrm{t}_{\mathrm{t}-1} \quad$ : Penjualan pada periode sebelumnya

Net Receivables $s_{t}$ : Piutang bersih pada periode berjalan

Net Receivables $\mathrm{t}-1 \quad$ : Piutang bersih pada periode sebelumnya

b. Gross Margin Index (GMI), digunakan untuk mengukur tingkat profitabilitas perusahaan, yang dapat menggambarkan prospek perusahaan di masa mendatang. Rasio ini dihitung menggunakan rumus:

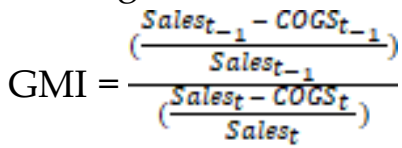

Dimana:

Sales $_{\mathrm{t}} \quad$ : Penjualan pada periode berjalan

Sales $\mathrm{t}_{-1}$ : Penjualan pada periode sebelumnya

$\mathrm{COGS}_{\mathrm{t}}$ : Beban pokok penjualan pada periode berjalan

COGS $_{\mathrm{t}-1}$ : Beban pokok penjualan pada periode sebelumnya

c. Asset Quality Index (AQI), digunakan untuk menunjukkan kualitas aset tidak lancar perusahaan yang mungkin dapat memberikan manfaat di masa mendatang. Rasio ini dihitung menggunakan rumus:

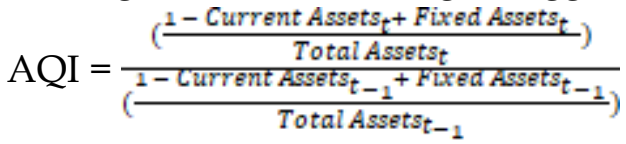

Dimana:

Current assets $s_{t}$ : Aset lancar pada periode berjalan

Current assets t $-1_{\text {: }}$ : Aset lancar pada periode sebelumnya

Fixed assets $\mathrm{s}_{\mathrm{t}} \quad$ : Aset tetap pada periode berjalan

Fixed assets $_{\mathrm{t}-1} \quad$ : Aset tetap pada periode sebelumnya

Total assets $\mathrm{s}_{\mathrm{t}} \quad$ : Jumlah aset pada periode berjalan

Total assets $_{\mathrm{t}-1} \quad$ : Jumlah aset pada periode sebelumnya

d. Sales Growth Index (SGI), digunakan untuk mengetahui tingkat penjualan perusahaan. Rasio ini dihitung menggunakan rumus:

$$
\text { SGI }=\frac{\text { Salest }_{t}}{\text { Salest }_{-1}}
$$


Zulzilawati dan Nanik Wahyuni : Beneish Ratio Index Sebagai Alat Deteksi Kecurangan Laporan Keuangan Pada Perusahaan Manufaktur

Dimana:

Sales $_{\mathrm{t}}:$ Penjualan pada periode berjalan

Sales $\mathrm{t}-1$ :Penjualan pada periode sebelumnya

e. Depreciation Index (DEPI), digunakan untuk mengukur keseuaian antara depresiasi yang terjadi dengan tingkat depresiasi, sehingga dapat diketahui depresiasi yang dilakukan mengalami pelambatan atau tidak sesuai dengan metode depresiasi yang digunakan. Rasio ini dihitung menggunakan rumus:

DEPI $=\frac{\left(\frac{\text { Depreciation }_{t-1}}{\text { Depreciation }_{t-1}+\text { Fixed Assetst-1 }_{t-1}}\right)}{\left(\frac{\text { Depreciation }_{t}}{\text { Depreciation }_{t}+\text { Fixed Assetsts }}\right)}$

Dimana:

Depreciation $_{\mathrm{t}}$ : Depresiasi pada periode berjalan

Depreciation $_{\mathrm{t}-1}$ : Depresiasi pada periode sebelumnya

Fixed assets $s_{t}$ : Aset tetap pada periode berjalan

Fixed assets $\mathrm{t}_{\mathrm{t}-1}$ : Aset tetap pada periode sebelumnya

f. Sales, General, and Administrative Expense Index (SGAI), digunakan untuk menggambarkan kemampuan perusahaan dalam menekan biaya secara efisien. Rasio ini dihitung menggunakan rumus:

$$
\text { SGAI }=\frac{\left(\frac{\text { SGAI }_{t}}{\text { Salest }_{t}}\right)}{\left(\frac{\text { SGAles }_{t-1}}{\text { Sales }_{t-1}}\right)}
$$

Dimana:

$\mathrm{SGAI}_{t}$ : Biaya penjualan, umum dan administrasi pada periode berjalan

$\mathrm{SGAI}_{\mathrm{t}-1}$ :Biaya penjualan, umum dan administrasi pada periode sebelumnya

Sales $_{\mathrm{t}} \quad$ : Penjualan pada periode berjalan

Sales $_{\mathrm{t}-1}$ : Penjualan pada periode sebelumnya

g. Leverage Index (LVGI), digunakan untuk mengetahui keadaan perusahaan melalui tingkat hutang yang dimiliki. Rasio ini dihitung menggunakan rumus:

$$
\text { LVGI }=\frac{\left(\frac{\text { Total Liabilities }_{t}}{\text { Total Assetst }}\right)}{\left(\frac{\text { Totallitablitites }}{\text { Total }_{t-1}}\right)}
$$

Dimana:

Total liabilities $_{\mathrm{t}}$ : Jumlah hutang pada periode berjalan

Total liabilities $_{\mathrm{t}-1}$ : Jumlah hutang pada periode sebelumnya

Total assets $_{\mathrm{t}} \quad$ : Jumlah aset pada periode berjalan

Total assets t $-1_{\text {I }} \quad$ : Jumlah aset pada periode sebelumnya

h. Total Accrual To Total Assets Index (TATA), digunakan untuk mengukur besarnya akrual perusahaan dengan total aset yang dimiliki. Rasio ini dihitung menggunakan rumus:

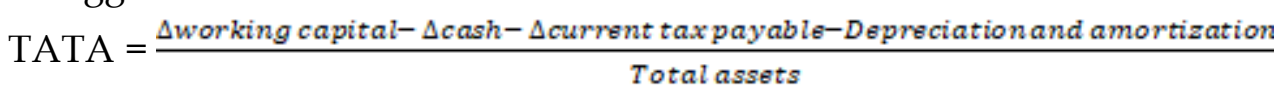

Dimana:

Aworking capital : Perubahan modal kerja

Acash

: Perubahan kas

EL MUHASABA Volume 12, No. 2, Tahun 2021|185 
Zulzilawati dan Nanik Wahyuni : Beneish Ratio Index Sebagai Alat Deteksi Kecurangan Laporan Keuangan Pada Perusahaan Manufaktur

Acurrent tax payable

: Perubahan hutang pajak

Depreciation and amortization : Depresiasi dan amortisasi

Total assets

: Jumlah aset

1. Melakukan perbandingan antara nilai indeks rasio dengan nilai indeks parameter

Tabel 1. Nilai Indeks Parameter Rasio

\begin{tabular}{|l|l|l|l|l|}
\hline \multirow{2}{*}{ No } & \multirow{2}{*}{ Rasio } & \multicolumn{3}{|l|}{ Indeks Parameter } \\
\cline { 3 - 5 } & & Non-Manipulator & Grey Company & Manipulator \\
\hline 1 & DSRI & $\leq 1,031$ & $1,031<$ index $<1,465$ & $\geq 1,465$ \\
\hline 2 & GMI & $\leq 1,014$ & $1,014<$ index $<1,193$ & $\geq 1,193$ \\
\hline 3 & AQI & $\leq 1,039$ & $1,039<$ index $<1,254$ & $\geq 1,254$ \\
\hline 4 & SGI & $\leq 1,134$ & $1,134<$ index $<1,607$ & $\geq 1,607$ \\
\hline 5 & DEPI & $\leq 1,001$ & $1,001<$ index $<1,077$ & $\geq 1,077$ \\
\hline 6 & SGAI & $\leq 1,054$ & $1,041<$ index $<1,054$ & $\geq 1,041$ \\
\hline 7 & LVGI & $\leq 1,037$ & $1,037<$ index $<1,111$ & $\geq 1,111$ \\
\hline 8 & TATA & $\leq 0,018$ & $0,018<$ index $<0,031$ & $\geq 0,031$ \\
\hline
\end{tabular}

Sumber : Beneish, 1999

2. Mengelompokkan perusahaan menjadi tiga golongan, yaitu perusahaan manipulator, perusahaan non-manipulator, atau grey company. Penggolongan ini didasarkan dengan ketentuan berikut: (Hadi et al., 2020)

a. Golongan manipulator, apabila:

1) Perusahaan memiliki $\geq 3$ (tiga) jenis indeks rasio yang mana indeks parameternya menyatakan manipulator

2) Perusahaan memiliki 3 (tiga) jenis indeks rasio yang mana indeks parameternya menyatakan manipulator, 2 (dua) jenis indeks rasio yang mana indeks parameternya menyatakan grey company, dan 3 (tiga) jenis indeks rasio yang mana indeks parameternya menyatakan non-manipulator

3) Perusahaan memiliki 4 (empat) jenis indeks rasio yang mana indeks parameternya menyatakan manipulator dan 4 (empat) jenis indeks rasio yang mana indeks parameternya menyatakan non-manipulator

4) Perusahaan memiliki 4 (empat) jenis indeks rasio yang mana indeks parameternya menyatakan manipulator dan 4 (empat) jenis indeks rasio yang mana indeks parameternya menyatakan grey company

b. Golongan non-manipulator, apabila perusahaan memiliki $\geq 3$ (tiga) jenis indeks rasio yang mana indeks parameternya menyatakan non-manipulator

c. Golongan grey company, apabila:

1) Perusahaan memiliki $\geq 3$ (tiga) jenis indeks rasio yang mana indeks parameternya menyatakan grey company dan indeks rasio tidak memenuhi 2 (dua) kriteria sebagai golongan manipulator dan golongan non-manipulator

2) Perusahaan memiliki 3 (tiga) jenis indeks rasio yang mana indeks parameternya menyatakan grey company, 2 (dua) jenis indeks rasio yang mana 
indeks parameternya menyatakan manipulator, dan 3 (tiga) jenis indeks rasio yang mana indeks parameternya menyatakan non-manipulator

3) Perusahaan memiliki 4 (empat) jenis indeks rasio yang mana indeks parameternya menyatakan grey company dan 4 (empat) jenis indeks rasio yang mana indeks parameternya menyatakan non-manipulator

3. Menghitung besarnya persentase dari jumlah perusahaan yang tergolong manipulator, non-manipulator dan grey company, antara lain:

a. Persentase perusahaan manipulator $=\frac{\text { Jumlah perusahaan manipulator }}{\text { Jumlahsampel }} \times 100 \%$

b. Persentase perusahaan non-manipulator $=\frac{\text { Jumlah perusahaan non-manipulator }}{\text { Jumlahsampel }} \times 100 \%$

c. Persentase perusahaan grey company $=\frac{\text { Jumlah perusahaan grey company }}{\text { Jumlah sampel }} \times 100 \%$

\section{HASIL DAN PEMBAHASAN}

\section{Analisis Hasil Perhitungan Rasio Indeks}

Nilai rata-rata dari hasil perhitungan setiap jenis rasio dapat menunjukkan adanya ketidakwajaran dalam laporan keuangan perusahaan, sebagai tanda bahwa kemungkinan suatu perusahaan telah melakukan kecurangan laporan keuangan. Pada rasio DSRI, diketahui bahwa sebanyak 33 perusahaan memiliki nilai rata-rata lebih dari satu (DSRI > 1). Artinya, sebagian besar perusahaan sampel mengalami peningkatan pada pos piutang. Peningkatan piutang dapat menjadi tanda-tanda adanya kecurangan, karena apabila peningkatannya tidak dibarengi dengan peningkatan penjualan secara proporsional, maka kemunginan perusahaan telah melakukan kecurangan pada pos penjualan (Harahap, 2017). Pada rasio GMI, diketahui bahwa sebanyak 20 perusahaan memiliki nilai rata-rata lebih dari satu (GMI > 1). Artinya, cukup banyak perusahaan sampel yang mengalami penurunan nilai margin kotor. Margin kotor yang rendah, menandakan keuangan perusahaan dalam kondisi yang tidak baik. Hal ini dapat menjadi salah satu factor penyebab suatu perusahaan melakukan kecurangan laporan keuangan (Christy dan Stephanus, 2018: 26)

Rasio yang ketiga adalah AQI, diketahui bahwa sebanyak 22 perusahaan memiliki nilai rata-rata lebih dari satu $(\mathrm{AQI}>1)$. Artinya, cukup banyak perusahaan sampel yang mengalami penurunan kualitas aset. Penurunan kualitas aset dapat menjadi tanda bahwa perusahaan kemungkinan telah melakukan penangguhan biaya. Penangguhan biaya tersebut menyebabkan nilai laba meningkat. Selanjutnya yaitu rasio SGI, diketahui bahwa sebanyak 49 perusahaan memiliki nilai rata-rata lebih dari satu (SGI > 1). Artinya, sebagian besar perusahaan sampel mengalami peningkatan penjualan. Peningkatan penjualan dapat menjadi salah satu faktor penyebab terjadinya kecurangan laporan keuangan. Hal ini dikarenakan untuk mempertahankan nilai penjualan yang dicapai perusahaan (Christy dan Stephanus, 2018: 26). Pada rasio DEPI, diketahui bahwa sebanyak 19 perusahaan memiliki nilai rata-rata lebih dari satu (DEPI > 1). Artinya, cukup banyak perusahaan sampel yang mengalami pelambatan depresiasi. Pelambatan depresiasi menyebabkan nilai biaya menjadi lebih kecil, sehingga laba yang diperoleh perusahaan mengalami peningkatan. 
Rasio berikutnya, yaitu SGAI. Diketahui bahwa sebanyak 31 perusahaan memiliki nilai rata-rata rasio SGAI lebih dari sama dengan satu (SGAI $\geq 1$ ). Artinya, sebagia besar perusahaan sampel mengalami penurunan efisiensi dalam menggunakan biaya usaha. Penurunan efisiensi pada biaya usaha yang berlangsung secara terus-menerus, dapat menyebabkan suatu perusahaan mengalami kerugian. Kerugian tersebut, dapat menjadi pemicu sutau perusahaan melakukan kecurangan (Apriani dan Nuzula, 2019: 228). Rasio yang ketujuh adalah LVGI, diketahui bahwa sebanyak 15 perusahaan memiliki nilai ratarata lebih dari satu (LVGI > 1). Artinya, cukup banyak perusahaan sampel yang mengalami peningkatan hutang. Terjadinya peningkatan hutang, menandakan bahwa perusahaan memiliki kewajiban yang semakin besar. Hal ini dapat memicu terjadinya kecurangan laporan keuangan, apabila keuangan perusahaan dalam keadaan tidak baik. Rasio yang terakhir adalah TATA, diketahui bahwa sebanyak 1 perusahaan memiliki nilai rata-rata rasio TATA yang bernilai positif. Artinya, tidak banyak perusahaan sampel yang mengalami peningkatan akrual. Adanya peningkatan akrual, menandakan bahwa kemungkinan telah terjadi earning overstatement melalui peningkatan akrual pada pengakuan pendapatan.

\section{Analisis Hasil Penggolongan}

Berdasarkan hasil perhitungan rasio-rasio keuangan, maka akan dilakukan pengelompokan perusahaan menjadi tiga golongan perusahaan, yaitu manipulator, nonmanipulator, dan grey company. Penggolongan dilakukan berdasarkan ketentuan yang telah ditetapkan sebelumnya (Latifatussolikhah dan Pertiwi, 2020: 170). Persentase perusahaan dalam masing-masing golongan, dihitung dengan cara membandingkan antara jumlah perusahaan yang tergolong dalam suatu kategori dengan jumlah sampel, kemudian dikali 100\%. Berikut nilai persentase pada setiap golongan:

Tabel 2. Perhitungan Persentase Perusahaan Manipulator, Non-Manipulator dan Grey Company

\begin{tabular}{|l|l|l|l|l|}
\hline Golongan & $\mathbf{2 0 1 6}$ & $\mathbf{2 0 1 7}$ & $\mathbf{2 0 1 8}$ & $\mathbf{2 0 1 9}$ \\
\hline Manipulator & $=\frac{2}{55} \times 100 \%$ & $=\frac{3}{55} \times 100 \%$ & $=\frac{2}{55} \times 100 \%$ & $=\frac{0}{55} \times 100 \%$ \\
\hline Non-Manipulator & $=\frac{48}{55} \times 100 \%$ & $=\frac{48}{55} \times 100 \%$ & $=\frac{48}{55} \times 100 \%$ & $=\frac{52}{55} \times 100 \%$ \\
$=87,27 \%$ & $=87,27 \%$ & $=87,27 \%$ & $=94,55 \%$ \\
\hline Grey Company & $=\frac{5}{55} \times 100 \%$ & $=\frac{4}{55} \times 100 \%$ & $=\frac{5}{55} \times 100 \%$ & $=\frac{3}{55} \times 100 \%$ \\
& $=9,09 \%$ & $=7,27 \%$ & $=9,09 \%$ & $=5,45 \%$ \\
\hline
\end{tabular}

\section{Sumber: Data diolah peneliti, 2021}

1. Manipulator

Nilai rata-rata persentase perusahaan yang tergolong sebagai manipulator adalah sebesar 3,18\%. Nilai rata-rata tersebut terbilang kecil, apabila dibandingkan dengan nilai rata-rata perusahaan yang tergolong non-manipulator. Meskipun demikian, 
keberadaannya menyimpan kerugian yang besar. Sehingga, investor dan kreditor diharapkan dapat berhati-hati dalam menanamkan modal dan memberikan pinjaman.

Berdasarkan hasil perhitungan rasio, diketahui bahwa rasio SGAI (Sales, General, and Administrative Expense Index) memiliki nilai rata-rata paling tinggi sebagai rasio yang menunjukkan manipulator. Hal ini dikuatkan oleh hasil penggolongan perusahaan, dimana sebesar $71 \%$ perusahaan yang tergolong manipulator memiliki rasio SGAI (Sales, General, and Administrative Expense Index) sebagai rasio yang menunjukkan manipulator. Hasil tersebut diperoleh dari lima perusahaan yang tergolong manipulator dibandingkan dengan total perusahaan yang tergolong manipulator selama tahun penelitian. Perusahaan-perusahaan yang dimaksud, yaitu Semen Baturaja (Persero) Tbk (SMBR, 2016), KMI Wire \& Cable Tbk (KBLI, 2017), Kabelindo Murni Tbk (KBLM, 2017), Supreme Cable Manufacturing \& Commerce Tbk (SCCO, 2017), dan Champion Pacific Indonesia Tbk (IGAR, 2018).

Kelima perusahaan tersebut memberikan gambaran bahwa sebagian besar perusahaan yang tergolong sebagai manipulator memiliki prospek yang buruk. Hal ini dikarenakan perusahaan mengalami kegagalan dalam melakukan efisiensi pada biaya. Apabila kegagalan tersebut terjadi secara terus-menerus, maka perusahaan dapat mengalami kerugian. Kerugian yang dialami suatu perusahaan, dapat menimbulkan suatu tekanan bagi manajemen. Sehingga, perusahaan yang merugi cenderung melakukan kecurangan laporan keuangan (Zimbelman et al., 2014: 43).

Beneish (1999) menyatakan bahwa perusahaan yang melakukan manipulasi bisanya memiliki beberapa ciri-ciri, yaitu perusahaan mengalami peningkatan piutang yang signifikan, mengalami penurunan laba kotor, mengalami penurunan kualitas aset, mengalami peningkatan penjualan yang signifikan, dan mengalami peningkatan akrual. Ciri-ciri tersebut dimiliki oleh perusahaan Waskita Beton Precast Tbk. Perusahaan yang memiliki kode WSBP tersebut, memiliki 4 jenis rasio yang menunjukkan manipulator. Rasio-rasio tersebut yaitu, DSRI (Days Sales In Receivables Index), AQI (Asset Quality Index), SGI (Sales Growth Index), dan TATA (Total Accrual To Total Assets Index). Artinya, perusahaan dengan kode WSBP tersebut mengalami peningkatan pada pos piutang, penurunan pada kualitas aset, peningkatan pada pos penjualan, dan peningkatan pada akrualnya.

Terlepas dari pernyataan yang diungkapkan oleh Beneish dalam jurnalnya, perusahaan yang melakukan manipulasi biasanya menyajikan nilai yang tinggi pada kekayaan dan keuntungannya. Hal ini dilakukan untuk menarik perhatian investor dan/atau kreditor. Sehingga, perusahaan mendapatkan tambahan modal dari investor dan/atau mendapat fasilitas pinjaman kredit dari kreditor (Heny \& Mitha, 2019).

2. Non-manipulator

Nilai rata-rata persentase perusahaan yang tergolong sebagai non-manipulator adalah sebesar $89,09 \%$. Nilai rata-rata tersebut terbilang jauh lebih besar, apabila dibandingkan dengan nilai rata-rata perusahaan yang tergolong manipulator dan grey company. Artinya, sebagian besar perusahaan yang menjadi sampel dalam penelitian ini, telah melaporkan laporan keuangannya sesuai dengan standar akuntansi keuangan. Hal ini didukung oleh opini auditor yang menyatakan wajar, pada seluruh laporan keuangan perusahaan yang tergolong non-manipulator. 
Sejatinya, perusahaan non-manipulator merupakan perusahaan yang terindikasi tidak melakukan manipulasi. Laporan keuangan yang disajikan oleh perusahaan dalam golongan ini, dinilai telah memenuhi karakteristik kualitatif laporan keuangan. Sehingga, perusahaan dianggap memiliki citra yang baik. Maka dari itu, perusahaan yang tegolong non-manipulator dapat menjadi bahan pertimbangan dalam mengambil keputusan bagi investor dan kreditor untuk menyalurkan dana yang dimiliki.

Perusahaan yang tergolong non-manipulator, dianggap dapat meningkatkan kepercayaan investor dan kreditor. Hal ini dikarenakan, laporan keuangan yang disajikan bebas dari kecurangan laporan keuangan, sehingga diharapkan investor dan kreditor tidak mengalami kerugian. Selain itu, resiko tingkat pengembalian modal investor dan tingkat kegagalan bayar atas dana pinjaman yang diberikan oleh kreditor menjadi lebih kecil (Efitasari, 2013).

\section{Grey Company}

Nilai rata-rata persentase perusahaan yang tergolong sebagai grey company adalah sebesar 7,73\%. Nilai rata-rata tersebut terbilang cukup besar, apabila dibandingkan dengan nilai rata-rata perusahaan yang tergolong manipulator. Perusahaan dalam golongan ini, tidak dapat dikatakan sebagai perusahaan manipulator. Hal ini dikarenakan nilai indeks rasio yang dimiliki tidak melebihi batas dari indeks parameter perusahaan manipulator. Hal ini berlaku juga untuk golongan non-manipulator, karena nilai indeks rasio yang dimiliki melebihi batas dari indeks parameter perusahaan non-manipulator. Maka dari itu, perusahaan yang tergolong grey company dianggap kemungkinan telah melakukan manipulasi dengan nilai yang tidak material. Meskipun tidak material, namun investor dan kreditor harus tetap berhati-hati dengan jenis perusahaan ini.

Berdasarkan hasil perhitungan rasio, diketahui bahwa rasio DSRI (Days Sales In Receivables Index) memiliki nilai rata-rata paling tinggi sebagai rasio yang menunjukkan grey company. Hal ini dikuatkan oleh hasil penggolongan perusahaan, dimana seluruh perusahaan yang tergolong grey company memiliki rasio DSRI (Days Sales In Receivables Index) yang menunjukkan grey company. Hal ini memberikan gambaran bahwa seluruh perusahaan yang tergolong sebagai grey company mengalami peningkatan piutang. Peningkatan piutang ini, dapat disebabkan oleh perubahan kebijakan penjualan kredit (Harahap, 2017). Namun, sejauh ini tidak ada perusahaan yang melakukan perubahan kebijakan penjualan kredit. Peningkatan piutang, terjadi karena perusahaan mengalami peningkatan penjualan.

Dalam perspektif keislaman, Kecurangan merupakan tindakan yang dilarang oleh Allah SWT. Larangan tersebut, terkandung dalam hadis Abu Dawud dan Sunan Abi Dawud. Dalam hadis tersebut dikatakan bahwa meskipun besarnya kecurangan hanya sebatang jarum atau lebih kecil dari itu, kecurangan tetap tidak boleh dilakukan. Sejatinya, sekecil apa pun kecurangan yang dilakukan keberadaannya tetap akan merugikan orang lain.

\section{KESIMPULAN DAN SARAN}

\section{Kesimpulan}

Berdasarkan analisis kecurangan laporan keuangan dengan menggunakan Beneish Ratio Index yang dilakukan pada perusahaan manufaktur yang terdaftar di Burna Efek 
Indonesia (BEI) pada tahun 2016-2019, diketahui bahwa pada tahun 2016 terdapat 48 perusahaan atau sebesar $87,27 \%$ tergolong sebagai non-manipulator. Kemudian, pada tahun 2017 sebanyak 48 perusahaan atau sebesar 87,27\% tergolong sebagai nonmanipulator. Pada tahun 2018, terdapat 48 perusahaan atau sebesar 87,27\% tergolong sebagai non-manipulator. Selanjutnya, pada tahun 2019 sebanyak 52 perusahaan atau sebesar $94,55 \%$ tergolong sebagai non-manipulator.

Berdasarkan analisis kecurangan laporan keuangan dengan menggunakan Beneish Ratio Index yang dilakukan pada perusahaan manufaktur yang terdaftar di Burna Efek Indonesia (BEI) pada tahun 2016-2019, diketahui bahwa pada tahun 2016 terdapat 5 perusahaan atau sebesar 9,09\% tergolong sebagai grey company. Kemudian, pada tahun 2017 sebanyak 4 perusahaan atau sebesar 7,27\% tergolong sebagai grey company. Pada tahun 2018, terdapat 5 perusahaan atau sebesar 9,09\% tergolong sebagai grey company. Selanjutnya, pada tahun 2019 sebanyak 3 perusahaan atau sebesar 5,45\% tergolong sebagai grey company.

\section{Saran}

Bagi peneliti selanjutnya, disarankan untuk menambah jangka waktu penelitian dan memperluas sampel penelitian. Sehingga, peneliti dapat memberikan gambaran mengenai fenomena kecurangan laporan keuangan pada berbagai jenis sektor. Kemudian, disarankan juga untuk melakukan analisa lebih lanjut seperti menganalisa faktor-faktor penyebab naik-turunnya jumlah perusahaan pada setiap golongan.

Bagi investor dan kreditor, hasil dari penelitian ini dapat digunakan sebagai peringatan untuk tetap berhati-hati dalam melakukan investasi dan memberikan pinjaman. Namun, disarankan untuk mencari informasi tambahan di luar laporan keuangan, seperti riwayat perjalanan perusahaan. Hal tersebut dikarenakan, hasil penelitian dalam skripsi ini hanya bersifat predictor, bukan mengklaim bahwa perusahaan yang tergolong manipulator dan grey company benar-benar melakukan kecurangan laporan keuangan.

\section{DAFTAR PUSTAKA}

Apriani, I. P., \& Nuzula, N. F. (2019). Analisis Pendeteksian Kecurangan Laporan Keuangan dengan Menggunakan Beneish Ratio Index (Studi Pada Perusahaan Sektor Manufaktur yang Terdaftar di Bursa Efek Indonesia Periode 2016-2017). Jurnal Administrasi Bisnis, 72(2), 224-233.

Association of Certified Fraud Examiners (ACFE). (2018). Report To the Nations 2018 Global Study on Occupational Fraud and Abuse.

Association of Certified Fraud Examiners (ACFE) Indonesia Chapter. (2019). Survei Fraud Indonesia 2019. Acfe Indonesia, 72.

Beneish, M. D. (1999). The Detection of Earnings Manipulation. Financial Analysts Journal. https:// doi.org/10.2469/faj.v55.n5.2296

Christy, Y. E., \& Stephanus, D. S. (2018). Pendeteksian Kecurangan Laporan Keuangan dengan Beneish M-Score pada Perusahaan Perbankan Terbuka. Jurnal Akuntansi Bisnis. https:// doi.org/10.24167/jab.v16i2.1560 
Zulzilawati dan Nanik Wahyuni : Beneish Ratio Index Sebagai Alat Deteksi Kecurangan Laporan Keuangan Pada Perusahaan Manufaktur

Dinasmara, C. K., \& Adiwibowo, A. S. (2020). Deteksi Kecurangan Laporan Keuangan Menggunakan Beneish M-Score dan Prediksi Kebengkrutan Menggunakan Altman ZScore (Studi Empiris pada Perusahaan yang Termasuk dalam Indeks LQ - 45 Tahun 2016 - 2018). Diponegoro Journal Of Accounting, 9(3), 1-15.

Hadi, A. N., Diana, N., \& Junaidi. (2020). Pendeteksian Kecurangan Laporan Keuangan (Financial Statement Fraud) Menggunakan Beneish Ratio Index Pada Perusahaan Manufaktur yang Listing Di Bursa Efek Indonesia (BEI) Tahun 2016-2018. Jurnal Ilmiah Riset Akuntansi.

Harahap, I. A. (2017). Analisis "Indexes" (Beneish Ratio Index) untuk Mendeteksi Kecurangan Laporan Keuangan Perusahaan Manufaktur yang Listing di BEI per Desember 2014-2015. Biomass Chem Eng.

Heny,T.K.,\& Mitha, A. S. (2019). Metode Beneish Ratio Index dalam Financial Statement Froud (Studi Kasus Perusahaan Konsumsi di Bursa Efek Indonesia). Jurnal Riset Akuntansi Multiparadgma (JRAM). 6(1),10-16

Hery. (2016). Audit dan Asuransi (Pemeriksaan Akuntansi Berbasis Standar Audit Internasional). Jakarta: PT Grasindo.

Https://mondovisione.com, diakses 18 Januari 2021, dari https://mondovisione.com/media-and-resources/news/securities-commissionmalaysia-former-megan-media-executive-chairman-jailed-for/.

Https://www.bbc.com, diakses 15 Januari 2021, dari https://www.bbc.com/news/world-asia-india-32229847.

Https:/ /www.cnnindonesia.com, diakses 10 Februari 2021, dari https:/ / www.cnnindonesia.com/ekonomi/20190430174733-92-390927/kronologikisruh-laporan-keuangan-garuda-indonesia.

Kurnianingsih, H. T., \& Siregar, M. A. (2019). "Metode Beneish Ratio Index dalam Pendeteksian Financial Statement Fraud ( Sudi Kasus Perusahaan Konsumsi di Bursa Efek Indonesia )." Jurnal Riset Akuntansi Multipradigma.

Latifatussolikhah, N., \& Pertiwi, D. A. (2020). Deteksi Financial Statement Fraud dengan Metode Beneish Ratio Index (Studi Kasus Perusahaan yang Melakukan Penawaran Saham Perdana ( IPO ) di Bursa Efek Indonesia Tahun 2018 ). 2(1), 162-176.

Omar, N., Koya, R. K., Sanusi, Z. M., \& Shafie, N. A. (2014). Financial Statement Fraud: A Case Examination Using Beneish Model and Ratio Analysis. International Journal of Trade, Economics and Finance. https:// doi.org/10.7763/ijtef.2014.v5.367.

Priantara D. (2013). Fraud Auditing E Investigation. Jakarta: Mitra Wacana Media.

Priyono. (2016). Metode Penelitian Kuantitatif. Sidoarjo: Zifatama Publishing.

Reflusmen R. (29 November 2010). Bangkrutnys Perusahaan Amerika, Penyebab Sederhana. 
Zulzilawati dan Nanik Wahyuni : Beneish Ratio Index Sebagai Alat Deteksi Kecurangan Laporan Keuangan Pada Perusahaan Manufaktur

Kompasiana. Diperoleh tanggal 13 Januari 2021 dari https://www.kompasiana.com/reflus/55004b06a33311a8725109d2/bangkrutnyaperusahaan-amerika-penyebabnya-sederhana

Www.idx.co.id

Zimbelman, M. F., Albercht, C. C., Albercht, W. S., \& Albercht, C. O. (2014). Akuntansi Forensik. In Salemba. 